\title{
OFFICERS OF THE AMERICAN POLITICAL SCIENCE ASSOCIATION
}

\begin{tabular}{|c|c|c|}
\hline & $\begin{array}{c}\text { President } \\
\text { ARTHUR W. MacmaHoN } \\
\text { Columbia University }\end{array}$ & \\
\hline $\begin{array}{c}\text { First Vice-President } \\
\text { QuINCY WrIGHT } \\
\text { University of Chicago }\end{array}$ & $\begin{array}{c}\text { Second Vice-President } \\
\text { V. O. KEY, Jn. } \\
\text { Johns Hopkins University }\end{array}$ & $\begin{array}{l}\text { Third Vice-President } \\
\text { CHaRLEs FarmaN } \\
\text { Stanford University }\end{array}$ \\
\hline $\begin{array}{l}\text { Secretary-Treasurer } \\
\text { KanNErE CoLmonovs } \\
\text { Northwestern Univeraity }\end{array}$ & $\begin{array}{c}\text { Assistant Secretary- } \\
\text { Treasurer }\end{array}$ & $\begin{array}{l}\text { Managino Editor } \\
\text { Frapara A. Oad }\end{array}$ \\
\hline thweste & $\begin{array}{l}\text { HARVET WALKFRR } \\
\text { Ohio State University }\end{array}$ & \\
\hline
\end{tabular}

\section{EXECUTIVE COUNCIL}

Above-named officers ex-officiis

EDWARD F. Dow
University of Maine
ROBERT J. HARRIs
Louisiana State University
JoHN G. HEINBERG
University of Missouri
WALTrR. H. C. LAvrs
U. S. Bureau of the Budget
CHEsTER C. MAXEY
Whitman College
RALPH J. BUNCHE
Howard University
RoBERT H. CoNNERY
Stanford University

Beule Zelleg

Charlegs McKinlet Reed College

C. Prrary Patterson

University of Teras

HABOLD 8. QUTaL:ST University of Minnesota

Tarror Cous

Duke University

Groncte A. Graham Princeton University

Llewhalyn Prankdchen University of Wisconsin

JoHN A. VIFG

Pomona College

Brooklyn College

Franx J. Goodnow

Albrat Shaw

Frederio N. Judeon

JAMES BaYcs

A. Lawbence Lowbl

Woodrow WItson

Simgon E. Baldwin

Albart Bushingll Hart

W. W. WILLOUGHBY

JoHn BAssetr Moong

Ernst Freund

Jagse Mact

MUNRO SMTTh

HENRY JONES FORD

FORMER PRESIDENTS

Pauz S. Ransach

LEo S. Rowe

Wilmam A. Donning

Hartit A. Garktithd

JaMes W. Garner

Charalas E. Merriasa

Charles A. Bmard

Wrltem B. MUnRO

Jasss S. Rigsves

Jogn A. Fatbite

Bemjamin F. Seambadar

Edward S. Corwts

Wrimax F. WinLodaher

Iswor Loms
W Alter J. Shepard

Francts W. Cokrar

Azthur N. Holcombe

Thomas Regi Powerch

Charencez A. Dykstra

Chardes Grovis Harnme

Robiar C. Broozs

Frimosnro A. Oco

WrLliay ANDERson

Rogmat E. Coshman

Lronard D. WhiTs

JoHN M. GaUs

Walter F. Dodd 
Copies of back issues of the AMERICAN POLITICAL SCIENCE REVIEW can be obtained at the following prices: Vol. I-X (1906-1916), \$1.50 per copy, except Feb., May, Aug., Nov. 1907, May 1908, Aug. 1910 and Nov. 1911, which are \$3.00 each. Vols. XI-XXV (1917-1931), \$1.25 per copy, except Feb., Aug. 1917, Nov. 1924, Feb., May, Aug. and Nov. 1925, Feb. 1926, Feb., May and Nov. 1927, Nov. 1928, May, Aug., Nov. 1929, May, Nov. 1930, and Feb. 1931, $\$ 1.50$ each; Feb. 1928 and Nov. 1929, \$3.00 each. Vols. XXVI (1932) and following $\$ 1.00$ per copy, except Feb. and Apr. 1932, Feb., June, Aug., Oct., Dec. 1934, all issues 1935, 1936, and 1937, Feb., June, Aug. and Dec. 1938, Feb., Apr., June, Aug., Oct. 1939, Apr., Oct., Dec. 1940, Aug. and Dec. 1943, Oct. 1945, Feb. 1946, \$1.50 each; Feb., 1940, Feb. 1941, Oct. 1943, Feb., Apr., June 1944, \$3.00 each. General Index, Vol. I-XX, \$1.00. Complete Volumes XII.XXI, XXV, XXVII, XL, $\$ 5.00$ per vol.; prices for other complete volumes furnished on request. Postage extra. Prices are subject to change. Some early issues are no longer available. Address: Kenneth Colegrove, SecretaryTreasurer, American Political Science Association, 1822 Sheridan Road, Evanston, Illinois.

\section{WANTED \\ Back Issues of the Review}

Only copies in good condition will be accepted.

Five dollars will be paid for the November 1906 issue, Vol. I, No. 1.

Fifty cents will be paid for each copy of the following issues: Feb., May, Aug. and Nov. 1907; Feb., May and Nov. 1908; Feb., May, Aug. and Nov. 1909; Feb., May and Aug. 1910; Feb., May and Nov. 1911; Nov. 1929; Feb. 1940; Feb. 1941; Oct. 1943; Oct. 1945; Feb. 1946.

Twenty-five cents will be paid for the following issues: Feb. and Aug. 1917; Feb., May and Nov. 1927; Feb. 1928; May and Aug. 1929; Feb. 1984; Feb., Aug. and Dec. 1935; Feb., Apr., June, Aug., Oct. and Dec. 1936; Feb. and Oct. 1937; June 1938; Feb., Apr. and June 1944.

\section{KENNETH COLEGROVE, Secretary-Treasurer}

1822 Sheridan Road, Northwestern University

Evanston, Illinois 


\section{POST WAR GOVERNMENTS OF EUROPE}

\section{-For Classes in Comparative Government-}

\section{Second Printing now available}

edited by-Professor David Fellman, University of Nebraska

Reprinted from the August Number of the "Journal of Politics"

1. Charles A. Micaud ...... "The Launching of the Fourth French Republic"

2. Max Ascoli .......... "Political Reconstruction in Italy"

3. Harold Zink ......... "American Military Government Organization in Germany"

4. Paul R. Sweet ........." "The New Austria: Notes on the First Year"

5. Karl R. Bopp ........ "Nationalization of the Bank of England and the Bank of France"

6. J. G. Heinberg ........ "Continuity and Change in European Governments"

7. John N. Hazard ........" "Russia Organizes for Reconstruction"

8. Eugene P. Chase ......."The Labor Government of Great Britain"

9. Eric C. Bellquist ......." "Government and Politics in the Smaller Countries of Northern Europe: An Appraisal of Recent Developments"

Useful as a Supplementary Text

$\$ 1.25$ Text-\$1.50 Trade

168 pages

\section{KALLMAN PUBLISHING COMPANY}

1870 W. University Ave.

Gainesville, Florida

\section{Directory of the American Political Science Association}

This Directory contains biographical sketches indicating education, academic experience, research activities, publications, and civic and governmental service of the various members of the Association; a list of members and subscribers according to geographical location; and a list of members classified according to their primary fields of competence in political science and the social sciences.

The Directory will be of service to appointing officers of educational institutions, research agencies, administrative bureaus, and government offices.

Orders should be addressed to the American Political Science Association, 1822 Sheridan Road, Evanston, Illinois.

\section{PRICES}

To members of the Association and subscribers to the American Political Science Review: Cloth bound, $\$ 2.00$; paper bound, $\$ 1.00$.

To non-members: Cloth bound, $\$ 3.00$; paper bound, $\$ 2.00$.

The Association will prepay postage on copies ordered with accompanying remittance. On other orders, mailing cost will be added to the price. 


\section{PRESIDENT AND CONGRESS}

\section{by Wilfred E. Binkley}

A historical analysis of the struggle between lawmakers and Chief Executives from Washington to Truman. Dr. Binkley details the resolution of the dilemma resulting from our constitutional system of checks and the necessity for cooperation between executive and legislative departments. Here, for student and citizen, is a work which illuminates the whole process of democratic legislation and leadership.

[March 1947] ix, 303, vii pages; \$4.00 net; \$3.0o text.

\section{TOTAL WAR AND THE CONSTITUTION}

\section{by Edward S. Corwin}

A cogent discussion of the way in which wartime Presidential powers have dislocated the governmental balance envisioned by the Constitution. The material in this book consists of lectures originally delivered under the auspices of the Cook Foundation at the University of Michigan.

[Just published] xiv, I82, vi pages; \$2.50 net.

\section{JAPAN PAST AND PRESENT}

\section{by Edwin O. Reischaver}

A brief interpretative history of Japan from earliest to modern times, emphasizing the political and social institutions of the past that have shaped the present Japan. From the origins of the Japanese people to their defeat in World War II, Dr. Reischauer omits nothing essential to explaining the rise and fall of this Asiatic empire. "I do not know of any short book on Japanese history which gives so much useful information in so brief and simple a form." SIR GEORGE SANSOM, Foreword.

[Just published] xiii, 192, xiv pages; $\$ 2.00$ net, $\$ 1.50$ text.

\section{For Spring Semester Classes}

Paul H. Appleby, BIG DEMOCRACY [1945] 206 pages; \$2.ro text

Carl L. Becker, FREEDOM AND RESPONSIBILITY IN THE AMERICAN WAY OF LIFE [1945] I68 pages; \$I.9o text

Wilfred E. Binkley, AMERICAN POLITICAL PARTIES:

[Second Edition 1945] 444 pages; \$3.00 text

Frederick L. Schuman, SOVIET POLITICS: At Home and Abroad

[1946] 7 ro pages; $\$ 3.75$ text

The College Department ALFRED A. KNOPF, Inc.

50I Madison Avenue New York 22 


\section{INTERNATIONAL ORGANIZATION}

A timely new periodical reviewing the entire program of the United $\mathrm{Na}$ tions and 34 other international agencies for 1946 in Articles by Philip Mosely, Leland Goodrich, Dwight E. Lee and others, Factual Summaries of Activities, with Documents section and selected Bibliography.

Published in

February, June, and September

Subscription Price $\$ 3.50$ a year

Single Copies $\$ 1.25$

\section{CHARTER OF THE UNITED NATIONS}

\section{Commentary and Documents}

\section{by LeLANd M. Goodrich aNd EdVARd Hambro}

"If a scholar can purchase only one book on the United Nations Charter this is it. While the authors explain that their work is not to be regarded as a 'thorough work of scholarship,' and hope only that 'this Commentary and the assembled documents will be of some assistance to the student and layman desiring a better understanding of the Charter as drafted at San Francisco' they have in fact produced a masterly factual guide and introduction to a badly drafted, turgid and confusing document."

-Llewellyn Pfankuchen in AMERICAN POLITICAL SCIENCE REVIEW

The second printing of this work is now available.

WORLD PEACE FOUNDATION

40 Mt. Vernon Street

Boston 8, Massachusetts 


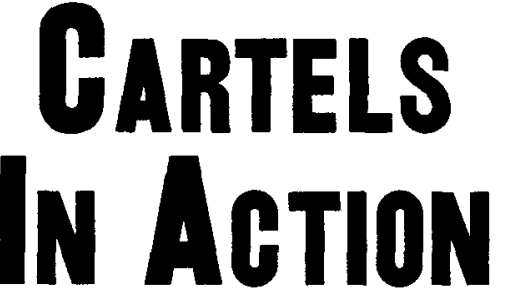

A Survey for

The Twentieth Century Fund

\section{GEORGE W. STOCKING and MYRON W. WATKINS \\ Research Directors}

A "case book" on international cartels-a factual account of the origins and operations of cartel arrangements in eight fields in which they have played a dominant role: sugar, rubber, nitrogen, steel, aluminum, magnesium, incandescent electric lamps, and chemicals. Important data for economists, businessmen, consumers, and all those concerned with establishing a sound economic basis for world peace. 545 pages. $\$ 4.00$

\section{FOR THIS WE FOUGHT}

By STUART CHASE. This sixth and final volume in a series of reports to The Twentieth Century Fund by Stuart Chase presents his framework of a practicable political and economic system whereby we may secure for the individual and the nation a truly abundant life.

135 pages, $\$ 1.00$

\section{TRENDS IN COLLECTIVE BARGAINING}

\section{A Summary of Recent Experience}

By S. T. WILLIAMSON and HERBERT HARRIS. A popular analysis of the problems and issues of collective bargaining, largely based on the Fund's extensive investigation of the process in 16 major industries.

272 pages. $\$ 2.00$

\section{FINANCING AMERICAN PROSPERITY: A Symposium of Economists}

Ediłed by PAUL T. HOMAN and FRITZ MACHLUP. Each of six leading economists-Benjamin M. Anderson, J. M. Clark, Howard S. Ellis, Alvin H. Hansen, Sumner H. Slichter, and John H. Williams-presents his own prescription for a healthy functioning of the economic system.

520 pages. $\$ 3.00$

\section{AMERICAN HOUSING: Problems and Prospects}

The Factual Findings by MILES L. COLEAN; The Program by the HOUSING COMMITTEE. A comprehensive investigation of how the housebuilding industry is organized and operated and how it might better serve the country's needs.

488 pages, 61 tables, 26 charts. $\$ 3.00$ 


\title{
a book for all who are concerned with civil rights \\ THE CONSTITUTION AND CIVIL RIGHTS
}

\section{By MILTON R. KONVITZ}

This is the first complete book on one phase of civil rights as developed under judicial decision and interpretation-the rights of persons to employment, accommodations in hotels, restaurants, common carriers and other public accommodations, without discrimination.

$\$ 3.00$

\section{both a warning and guide THE PROCESS OF}

\section{INTERNATIONAL ARBITRATION}

\author{
$B y$ KENNETH S. CARLSTON
}

This is a thorough study of the technique of international arbitration and the principles involved in the functioning of international courts. The book should be of utmost value to governments, to arbitrators, to attorneys, and to students.

$\$ 4.50$

Columbia University Press 


\title{
Coming in March
}

\section{THE AMERICAN FEDERAL GOVERNMENT}

\author{
By JoHn H. Ferguson \\ Associate Professor of Political Science \\ Pennsylvania State College \\ and Dean E. McHenry \\ Associate Professor of Political Science \\ University of California at Los Angeles
}

\section{McGraw-Hill Series in Political Science}

This postwar college text covers the essential features of the American system of government. In it the authors have striven to present controversial matters objectively, and to avoid being either too elementary and general on the one hand or too advanced and detailed on the other. The present book is a part of a larger volume to be published later which will encompass government at all levels-national, state, and local.

Part I of the present book deals with the historical background, general principles, and other essentials, including a separate treatment of federal powers. Part II is devoted to administrative organization and functions of the federal government, including Congress, the President, courts, and federal powers. The materials are intended to acquaint the student with both the older and newer federal programs. Part III covers governmental functions.

\section{Some special features of the book:}

The book offers timely treatments of foreign relations and the United Nations; federal powers; federally owned and operated enterprises ; compulsory military training; and control of atomic energy.

The text is fully illustrated. The numerous pictorial aids include charts, graphs, and summaries which should make the subject matter clearer and more meaningful to the reader.

Stress has been placed on the role of pressure groups in American government. An innovation is the coverage given to the formation, measurement, and nature of public opinion.

Another unusual feature is the emphasis given to the channels of mass communication-press, radio, and motion pictures.

There is a comprehensive discussion of interstate and federal-state relations.

The chapter on labor is thorough and points up recent controversies in the field.

Send for a copy on approval

\section{McGRAW-HILL BOOK COMPANY, INC.}




\section{Elements of Public Administration}

By F. Morstein Marx and collaborafors

- COMING SOON, an outstanding new study of public administration combining sound academic background with actual government experience. Fourteen professors have contributed to this unified text. stressing throughout the implications of democratic governance for public management in all its ramifications.

Notice these important features:

- Gives fundamental problems in the administrative process, and follows them through the entire system.

- Crystallizes the operating spirit of government.

- Furnishes a mature understanding of public administration in the modern service state.

College List, $\$ 5.00$

\section{American Government}

By W. Reed West, George Washington University

- On the conviction that real understanding of our governmental organization or political problems requires a foundation in constitutional theory, Professor West has stressed constitutional aspects more heavily than most authors do.

In addition, his use of the unified system of exposition avoids the repetition of the traditional system, and the confusing cross-references of the functional system. The text is divided into six main parts:

- Political Theory

- The Federal Government

- State and Local Governments

- The forces, such as parties, that formulate policies and furnish the motive force for these governments.

- Limitations upon the exereise of governmental power in relation to the individual.

- The activities of government.

College List, $\$ 4.25$

Send for your approval copies 


\title{
The GOVERNMENT of the AMERICAN PEOPLE
}

\author{
By EARL L. SHOUP \\ Western Reserve University
}

An authoritative book that presents government in action. It gives an accurate view of the American system of government by relating its structure, objectives, and functioning to the political activities of the people. The all-over process of government is treated sequentially, starting with the political character of the people, public opinion, political associations of citizens, nominations, elections. This is followed by an account of the various methods of lawmaking, the organization of administration, and a description of the duties of the people as citizens. Foreign relations and policy also included.

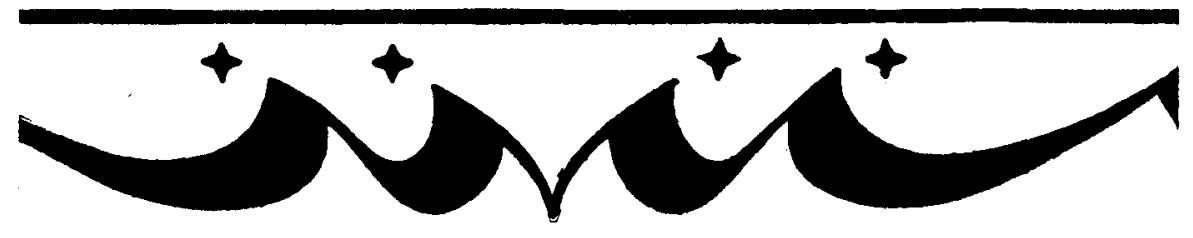

\section{GINN AND COMPANY}

Boston 17 New York 11 Chicago 16

Atlanta 3 Dallas 1 Columbus 16 San Francisco 5 Toronto 5 


\title{
Comparative Economic Systems
}

By RALPH H. BLODGETT

Associate Professor of Economics, University of Illinois

The first part of this college text analyzes, compares, and evaluates capitalism, theoretical socialism, theoretical communism, practical socialism in Soviet Russia, fascism in Italy, and National Socialism in Germany. The systems of Russia, Italy and Germany receive particularly rigorous treatment. Part two is devoted to an unusually thorough analysis, interpretation and criticism of Marxian Socialism. The book is organized by topics, the same list of topics beng discussed in connection with all systems. Summary chapters give pictures of each system as a whole.

$\$ 4.40$

\section{Chile: An Economy in Transition}

\author{
By P. T. ELLSWORTH \\ Professor of Economics, University of Wisconsin
}

A noted economist here discusses the measures taken to equalize Chile's foreign trade when, in the 1930's, all semblance of equilibrium in her balance of payments was destroyed when the markets for her raw materials collapsed. The detailed analysis of these events is a significant and informative case study of national and international economy and of the relation of government to foreign trade and international economic functions.

$\$ 3.30$

The Macmillan Company 


\title{
STANDARD CROWELL TEXTS
}

\section{GOVERNMENT IN THE UNITED STATES}

\author{
by Claudius 0 . Jobnson
}

An extremely readable and stimulating treatment of all levels of American government. The third edition continues to emphasize the functions of each governmental branch.

Third Edition, $1944 \quad 852$ pages $\$ 4.00$

\section{AMERICAN NATIONAL GOVERNMENT}

by Claudius O. Jobnson

An introductory text containing all pertinent material from the author's larger book, including its treatment of past and present participation in international affairs.

$1945 \quad 594$ pages $\$ 3.25$

\section{AMERICAN STATE GOVERNMENT AND ADMINISTRATION}

by Austin F. Macdonald

A thorough treatment of state governments, tracing their new role in our developing federal system.

Third Edition, $1945 \quad 655$ pages $\$ 4.00$

\section{AMERICAN CITY GOVERNMENT AND ADMINISTRATION}

by Austin F. Macdonald

A fourth edition of this well-known text, published in September, thoroughly revised and completely reset.

Fourth Edition, $1946 \quad 657$ pages $\$ \$ 4.00$

\section{MODERN WORLD POLITICS}

by Thorsten $V$. Kalijarvi and Associates

A text on international relations, presenting a realistic review of the world political scene and power politics.

Second Edition, $1945 \quad 852$ pages, 62 pages of maps $\$ 4.00$

\section{POLITICS, PARTIES AND PRESSURE GROUPS}

$$
\text { by V.O. Key, Jr. }
$$

A study of political parties with an extensive treatment of pressure groups and political techniques.

$$
1942 \quad 814 \text { pages } \$ 4.00
$$

\section{INTRODUCTION TO POLITICS}

by Roy V. Peel, Joseph S. Roucek and Associates

An introduction to the field of political science emphasizing functional rather than legalistic and descriptive aspects.

$1941 \quad 587$ pages $\quad \$ 4.00$

\section{Send For Examination Copies}

\section{THOMAS Y. CROWELL COMPANY}

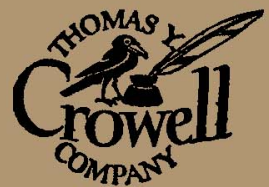




\title{
TEXTBOOK NEWS
}

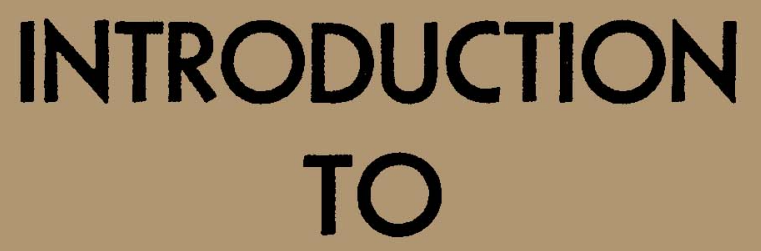

\section{AMERICAN \\ GOVERNMENT \\ 8th Edition}

\author{
By
}

Frederic A. OGg and P. Orman Ray

\section{INTRODUCTION TO}

AMERICAN

GOVERNMENT:

THE NATIONAL GOVERNMENT

\section{8th Edition}

